Antonella Macerollo, $\mathrm{MD}^{*}$

Walter Struhal, MD* Johann Sellner, MD

Correspondence to Dr. Macerollo: antonella.mac@hotmail.com

\section{HARMONIZATION OF EUROPEAN NEUROLOGY EDUCATION: THE JUNIOR DOCTOR'S PERSPECTIVE}

The objective of this article, written by executives of the European Association of Young Neurologists and Trainees (EAYNT), is to illustrate the status quo of neurology training in Europe and give an outlook on ongoing efforts and prospects for junior neurologists. The European Union (EU) is an economic and political union that currently encompasses 27 member states with more than 500 million inhabitants (or 7.3\% of the world population) (interested readers are referred to http://en.wikipedia.org/wiki/European_Union). Countries of the EU act as a single market with free movement of citizens, goods, services, and finances. As a consequence, a diploma and postgraduate training obtained in one EU country will be automatically recognized by all other EU member states. At the Lisbon European Council in March 2000, the Heads of State or Government signed a treaty that expresses their ambition of making Europe "the most competitive and dynamic knowledge-based economy in the world, capable of sustainable economic growth with more and better jobs and greater social cohesion" (www.en. wikipedia.org/wiki/Lisbon_Strategy). More than 1.6 million physicians in all the different medical specialties are represented by the European Union of Medical Specialists (UEMS). The UEMS was founded in 1958 and the objectives include the study, promotion, and harmonization of the highest level of training of medical specialists, medical practice, and health care within the European Union. The European Board of Neurology (UEMSEBN; www.uems-neuroboard.org) is in charge of the implementation of the UEMS policy regarding neurology.

European neurology can take pride in its long tradition and is an established specialty in all EU member states. Yet clinical practice is distinguished by inconsistency in training, concepts of patient care, and resources. ${ }^{1}$ Most recently, the EBN revised the training charter defining the issues of training and continuing medical education.

Status quo of neurology training. Education, including medical specialty training, in the EU is maintained by the "subsidiarity" principle and is subsequently a national matter. Our survey of neurology residency training in 21 EU member states (2006-2009) confirmed a wide spectrum of standards for training and patient care. ${ }^{2}$ The main differences pertained to manpower, training, and training framework (table). For instance, the prevalence of neurologists was lowest in the United Kingdom $(0.9 / 100,000)$ and highest in the Slovak Republic (12.5). There are still countries lacking a training curriculum, an obligatory logbook, or regularly scheduled teaching sessions. Duration of neurology residency spans from 4 to 6 years, and total working hours per week may go up to 56 hours (Spain). Interestingly, rotation or board examination is not required in some EU countries. The majority of board-certified neurologists in the EU countries are hospital-based, with exceptions for Belgium, Greece, Iceland, Italy, Latvia, Romania, and the Slovak Republic. Whereas unemployment of neurologists is low in most EU countries, this is not the case in Greece $(17 \%$, $200 / 1200)$, Italy $(10 \%, 350 / 3500)$, and Latvia (12\%, $34 / 274)$. Another study revealed that remuneration for neurology trainees varies considerably among EU countries. Frontrunners are the United Kingdom and Denmark, whereas salaries in Greece, France, and Italy were lowest. ${ }^{3}$ Harmonization not only of training quality but also of working time and salaries is an important issue. These inequalities, in combination with the lack of training positions, have led to migration of young doctors within the EU. The demand for medical doctors and subsequent number of admissions to medical school is calculated on national requirements in most EU countries and does not take EU-wide migration of

\footnotetext{
*These authors contributed equally to this work.

From the Sobell Department of Motor Neuroscience and Movement Disorders (A.M.), The National Hospital of Neurology and Neurosurgery, Institute of Neurology, University College London, UK; the Department of Neuroscience and Sense Organs (A.M.), Aldo Moro University of Bari, Italy; the Department of Neurology (W.S.), General Hospital of the City of Linz, Austria; the Department of Neurology (J.S.), Klinikum rechts der Isar, Technische Universität München, Germany; and the Department of Neurology (J.S.), Christian-Doppler-Klinik, Paracelsus Medical University, Salzburg, Austria.

Go to Neurology.org for full disclosures. Funding information and disclosures deemed relevant by the authors, if any, are provided at the end of the article.
} 


\begin{tabular}{|c|c|c|c|c|c|c|c|c|c|c|c|c|c|}
\hline Table & nditions of $n$ & neurology & residency trainir & ng in 21 countries & of the European & Union (surve & from 2006 to 2 & 09) & & & & & \\
\hline Country & Population $^{a}$ & Income ${ }^{b}$ & $\begin{array}{l}\text { Neurologists per } \\
100,000 \\
\text { inhabitants }\end{array}$ & $\begin{array}{l}\text { National training } \\
\text { program }\end{array}$ & $\begin{array}{l}\text { National training } \\
\text { structured }\end{array}$ & $\begin{array}{l}\text { Duration of } \\
\text { training, } y\end{array}$ & $\begin{array}{l}\text { Training in } \\
\text { neurology, mo }\end{array}$ & $\begin{array}{l}\text { Structured } \\
\text { teaching }\end{array}$ & $\begin{array}{l}\text { Obligatory } \\
\text { logbook }\end{array}$ & Rotation & Assessment & $\begin{array}{l}\text { Board } \\
\text { examination }\end{array}$ & $\begin{array}{l}\text { Total working } \\
\text { hours, wk }\end{array}$ \\
\hline Austria & 8.4 & High & 9.6 & * & * & 6 & 48 & * & & & * & * & 48 \\
\hline Belgium & 11.0 & High & 6.5 & & & 5 & 60 & * & * & & * & * & 40 \\
\hline Bulgaria & 7.5 & $\begin{array}{l}\text { Lower } \\
\text { middle }\end{array}$ & 11.7 & * & * & 4 & 29 & & * & * & & * & 30 \\
\hline Czech Republic & 10.5 & $\begin{array}{l}\text { Higher } \\
\text { middle }\end{array}$ & 6.3 & * & * & 5 & 51 & * & * & * & * & * & 43 \\
\hline Estonia & 1.3 & $\begin{array}{l}\text { Higher } \\
\text { middle }\end{array}$ & 9.4 & * & * & 5 & 25 & * & * & * & * & * & 40 \\
\hline Finland & 5.4 & High & 6.3 & & & 6 & 48 & & * & & & * & 38 \\
\hline Germany & 81.6 & High & 5.5 & * & * & 5 & 36 & * & & & * & * & 40 \\
\hline Greece & 11.3 & High & 10.9 & * & & 5 & 36 & * & & & . & * & 39 \\
\hline Hungary & 10 & High & 6.0 & * & * & 5 & 42 & * & & * & * & * & 40 \\
\hline Italy & 60.6 & High & 5.9 & * & * & 5 & 30 & * & * & & * & * & 38 \\
\hline Latvia & 2.2 & $\begin{array}{l}\text { Lower } \\
\text { middle }\end{array}$ & 12.0 & * & * & 5 & 44 & & * & * & * & * & 40 \\
\hline Lithuania & 3.3 & $\begin{array}{l}\text { Lower } \\
\text { middle }\end{array}$ & 8.9 & * & * & 4 & 24 & * & * & * & * & * & 40 \\
\hline Luxembourg & 0.5 & High & 4.6 & & & 4 & 48 & & & & & & \\
\hline Netherlands & 16.7 & High & 4.7 & * & * & 6 & & * & * & * & * & & 48 \\
\hline Portugal & 10.6 & High & 3.4 & * & * & 5 & 24 & & & & * & * & 42 \\
\hline Romania & 21.4 & $\begin{array}{l}\text { Lower } \\
\text { middle }\end{array}$ & 4.4 & * & * & 5 & 36 & * & & * & * & * & 35 \\
\hline Slovenia & 2.1 & High & 4.2 & * & * & 6 & 48 & & * & * & * & * & 40 \\
\hline $\begin{array}{l}\text { Slovak } \\
\text { Republic }\end{array}$ & 5.4 & $\begin{array}{l}\text { Higher } \\
\text { middle }\end{array}$ & 12.5 & * & & 5 & 46 & & * & & * & * & 40 \\
\hline Spain & 47.2 & High & 4.4 & * & * & 4 & 36 & & & * & * & & 56 \\
\hline Sweden & 9.4 & High & 3.8 & & & 5 & 36 & & & & & & 40 \\
\hline UK & 62.4 & High & 0.9 & * & * & 5 & 60 & * & * & * & * & * & 40 \\
\hline
\end{tabular}

Adapted from reference 2 .

a In millions, according to www.wikipedia.org, accessed on January 21, 2013.

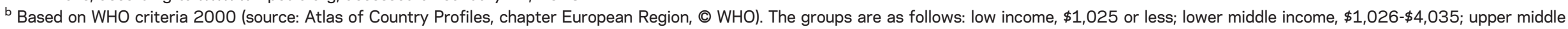
income, $\$ 4,036-\$ 12,475$; and high income, $\$ 12,476$ or more. 
recent graduates and specialists into account. In addition, medical school graduates also see career prospects beyond patient care, e.g., the pharmaceutical industry and hospital management. Financially strong countries with a shortage of physicians have been successfully recruiting across EU borders at both the resident and specialist level. These factors, together with rural depopulation, present a major threat to adequate patient care in certain regions.

Current efforts toward harmonization of neurology training. Promotion and harmonization of a medical specialty at the EU level toward the highest level of training is a great challenge. There are historical and economical issues to be considered and ambitious intervention may jeopardize cultural diversity and national identity. Back in 1994, the UEMS started to develop a European core curriculum for each subspecialty. The EBN presented a revision in 2011 defining general aspects of training, training method, and content, as well as requirements for training institutions, educators, and trainees (for details see http:// www.uems-neuroboard.org/html/docs/Chapter_6_ Neurology_2011.pdf). Further efforts toward harmonization of neurology training include a voluntary hospital visitation and the EBN examination. The visitation is aimed to assess educational structures and is performed on-site by an EBN/UEMS representative as well as a national delegate. The EBN examination was launched in 2009 and is held annually

\section{Figure Demographic distribution of successful examinees of the European Board of Neurology}

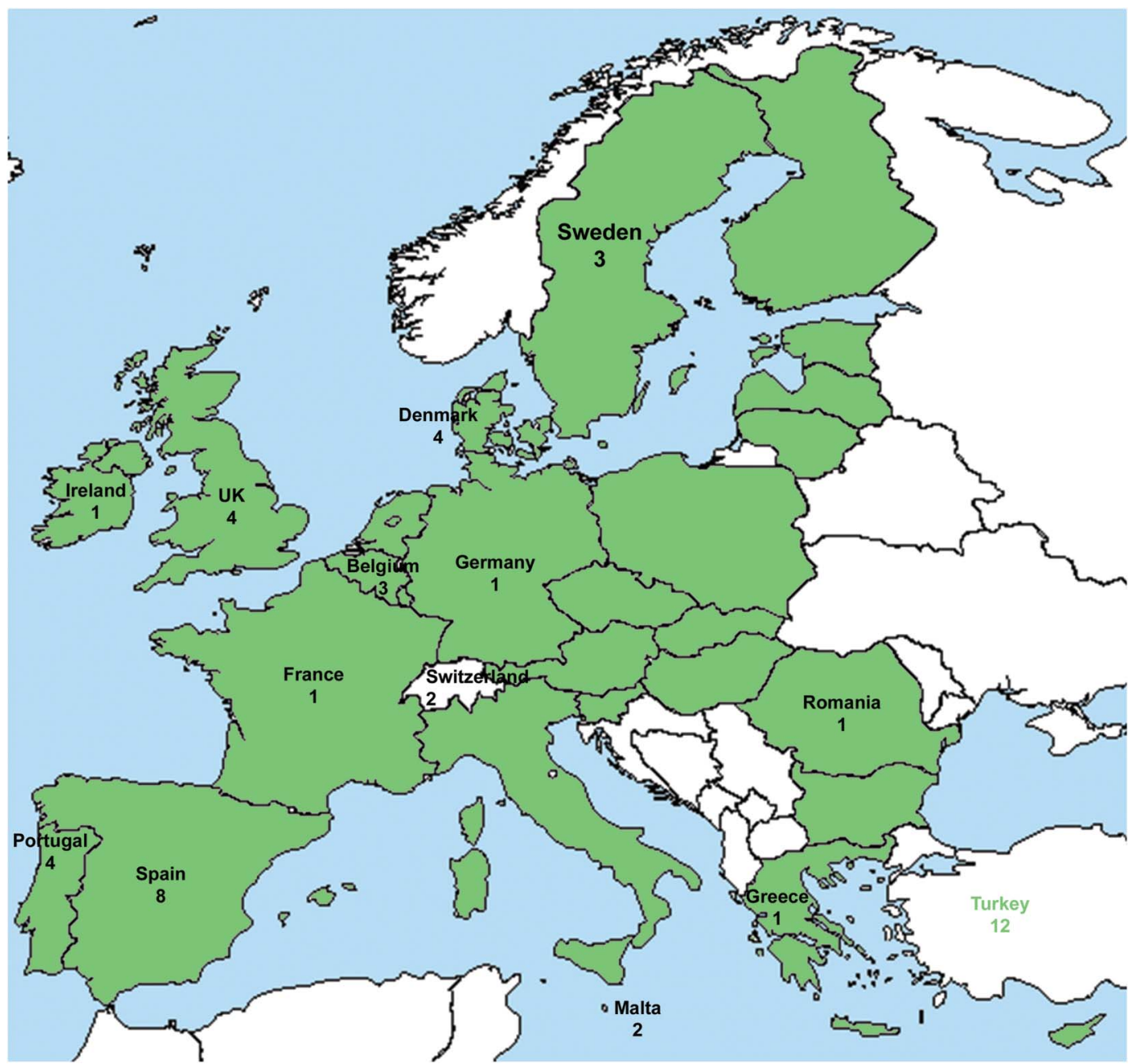

The map shows the number of fellows for each country. The successful candidates come from Portugal, Sweden, the United Kingdom, Switzerland, Spain, Germany, Turkey, Iran, Belgium, Romania, Malta, France, Denmark, and Greece. In 2012, there was the first fellow from the United Arab Emirates (not shown). The European Union (EU) countries are shown in green (data were retrieved from www.uems-neuroboard.org on January 25, 2013). The European Union of Medical Specialists (UEMS) European Board of Neurology examination has been limited up to now to persons from UEMS member countries, Canada, the United States, and Turkey, but from 2013 on it will be open worldwide. Successful candidates from the UEMS member countries will be conferred the title Fellow of the European Board of Neurology, whereas those from other, non-EU countries will receive a diploma acknowledging their successful participation in the examination (http://www.ensinfo.org/letter_to publish/index.html). 
at one of the 2 major European conferences. At the moment, only 2 European countries (Austria, Belgium) accept this examination alternatively to the national board certification. A list of successful candidates is shown in the figure. The individual motives of the examinees are unclear. The interest in a certificate of excellence or improvement of prospects, e.g., for relocating to another country, may have played a role. The low number of applicants in the first years prompted us to analyze the motivation of European junior neurologists for this examination. ${ }^{4}$ Among the major issues were language barriers (examination oral and written in English), costs of the examination, and related expenses as well as suggested textbooks. The latter may change with the consideration of ebrain, the world's largest online neurology learning program, as a recommended preparation resource (www.ebrainjnc. com). Ebrain, launched in 2012, is an interactive Web-based training resource in clinical neuroscience and is freely accessible for members of national clinical neurology societies in Europe. Whether ebrain may become a key tool in the harmonization process of neurology will need to be proven.

Emerging opportunities for junior neurologists. A uniform quality assurance in education will be of benefit for patient care and mobility, and strengthen the position of European neurology in the world. It can be hoped that further countries will recognize the EBN examination alternatively to the national board examination in the near future. In the meantime, junior colleagues are encouraged to obtain this certificate of European standards and excellence. European junior colleagues should gain knowledge in the spectrum of pan-European neurology and get familiar with country- and region-specific approaches toward neurology practice. In this regard, the EAYNT organizes hospital visits and meetings with local residents during major European neurology conferences to highlight country-specific issues in the approach to patient care and training. The continuation of international friendships is supported by their own Internet platform (www.eaynt.org) and on Facebook (www.facebook.com/EAYNT).

Specialist training is an amalgam of scientific knowledge plus practical skills necessitating time spent actually at the bedside and in laboratories, ideally at a leading department in the field. There are an increasing number of educational fellowships for junior colleagues to spend a training period in another European country. Such stipends are provided by both national and European neurology associations as well as subspecialty societies. Insights to the cultural diversity of neurology can also be gained by attending European neurology conferences and debates with international colleagues. The EAYNT maintains an exchange program called "Open Facilities for Training in European Neurology" on behalf of the EBN. ${ }^{5}$ Through this program, a training period of 3 to 12 months can be arranged and offers specialist training in one of the 106 participating neurology departments across Europe (the list of departments can be accessed in the member section of www.eaynt.org). In addition to postgraduate degrees in clinical neurology, there are an increasing number of further opportunities devoted to postgraduate education in various subspecialties (e.g., MSc for stroke, rehabilitation, or dementia).

Conclusion. Medical care and education in the EU is a national responsibility and characterized by a broad spectrum of standards, which can be traced back to a variety of economic, historical, and region-specific developments. Junior neurologists need to be aware of the European educational harmonization process and interested in potential measures to improve their prospects for training and patient care. On the other hand, the establishment of European standards will provide the basis for quality assurance in medical training and patient care. Eventually, harmonization of training standards will create the grassroots for international recognition in the medical and scientific community and strengthen the position of European medicine in the world.

\section{AUTHOR CONTRIBUTIONS}

Antonella Macerollo: design and conceptualization of the study, analysis and interpretation of the data, drafting and revising the manuscript. Walter Struhal: design and conceptualization of the study, analysis and interpretation of the data, drafting and revising the manuscript. Johann Sellner: design and conceptualization of the study, analysis and interpretation of the data, drafting and revising the manuscript.

\section{STUDY FUNDING}

No targeted funding reported.

\section{DISCLOSURE}

The authors report no disclosures relevant to the manuscript. Go to Neurology.org for full disclosures.

\section{REFERENCES}

1. Grisold W, Galvin R, Lisnic V, et al. UEMS-EBN and EFNS Education Committee: One Europe, one neurologist? Eur J Neurol 2007;14:241-247.

2. Struhal W, Sellner J, Lisnic V, Vécsei L, Müller E, Grisold W. Neurology residency training in Europe: the current situation. Eur J Neurol 2011;18:e36-e40.

3. Corea F, Bacigaluppi M. Postgraduate medical training and migration in Europe: a survey of financial and labour conditions. J Public Health 2010;18:53-57.

4. Struhal W, Rakusa M, Grisold W, Sellner J. The European Board of Neurology Examination: junior neurologists are eager to take the challenge. Eur J Neurol 2011;18:e89-e92.

5. Sellner J, Schirmer L, Gilhus NE, Grisold W, Struhal W. The Open Facilities for Training in European Neurology (OFTEN): an emerging pan-European exchange programme for junior neurologists. Eur J Neurol 2012;19:e54-e55. 


\section{Neurology}

Harmonization of European neurology education: The junior doctor's perspective Antonella Macerollo, Walter Struhal and Johann Sellner Neurology 2013;81;1626-1629

DOI 10.1212/WNL.0b013e3182a9f3ed

This information is current as of October 28, 2013

\begin{tabular}{|c|c|}
\hline $\begin{array}{l}\text { Updated Information \& } \\
\text { Services }\end{array}$ & $\begin{array}{l}\text { including high resolution figures, can be found at: } \\
\text { http://n.neurology.org/content/81/18/1626.full }\end{array}$ \\
\hline References & $\begin{array}{l}\text { This article cites } 5 \text { articles, } 0 \text { of which you can access for free at: } \\
\text { http://n.neurology.org/content/81/18/1626.full\#ref-list- } 1\end{array}$ \\
\hline Citations & $\begin{array}{l}\text { This article has been cited by } 1 \text { HighWire-hosted articles: } \\
\text { http://n.neurology.org/content/81/18/1626.full\#\#otherarticles }\end{array}$ \\
\hline Subspecialty Collections & $\begin{array}{l}\text { This article, along with others on similar topics, appears in the } \\
\text { following collection(s): } \\
\text { Training-international } \\
\text { http://n.neurology.org/cgi/collection/training_international }\end{array}$ \\
\hline Permissions \& Licensing & $\begin{array}{l}\text { Information about reproducing this article in parts (figures,tables) or in } \\
\text { its entirety can be found online at: } \\
\text { http://www.neurology.org/about/about_the_journal\#permissions }\end{array}$ \\
\hline Reprints & $\begin{array}{l}\text { Information about ordering reprints can be found online: } \\
\text { http://n.neurology.org/subscribers/advertise }\end{array}$ \\
\hline
\end{tabular}

Neurology ${ }^{\circledR}$ is the official journal of the American Academy of Neurology. Published continuously since 1951, it is now a weekly with 48 issues per year. Copyright (C 2013 American Academy of Neurology. All rights reserved. Print ISSN: 0028-3878. Online ISSN: 1526-632X.

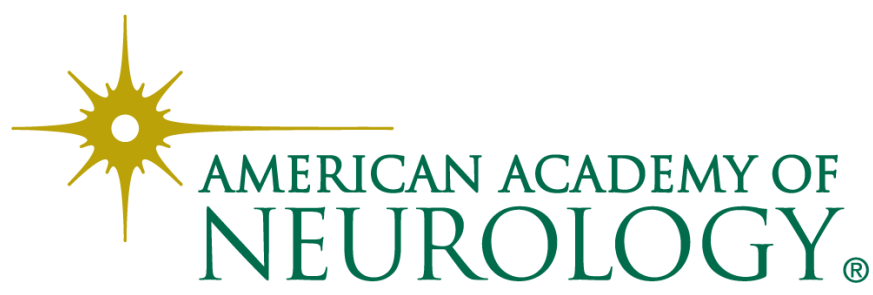

